\title{
On Economy of Fuel in Ships of War
}

\section{T. Symes Prideaux Esq., C.E.}

To cite this article: T. Symes Prideaux Esq., C.E. (1872) On Economy of Fuel in Ships of War, Royal United Services Institution. Journal, 16:68, 315-342, DOI: 10.1080/03071847209417078

To link to this article: http://dx.doi.org/10.1080/03071847209417078

册 Published online: 11 Sep 2009.

Submit your article to this journal

Џlll Article views: 3

Q View related articles $₫$ 


\title{
Tlitẹ Gountul \\ OF TEE

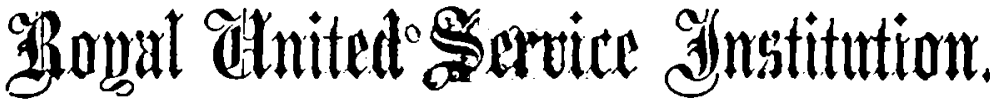

VoL. XVI. $1872 \quad \begin{aligned} & \text { No. LXVIII } \\ & \text { (Dowble Nember). }\end{aligned}$ \\ (Ebening aflectimg.
}

\author{
Monday, Mrarch 18th, 1872. \\ Aduipal TuE RIGHT HON. THOMAS, EARL OF \\ LAUDERDALE, K.C.B., in the Chair.
}

NAIIES OF MLEJIBERS who joined the Institution betreen the 5th and 18th March, $18 \% 2$.

\section{LIFF.}

Suffield, Rigitt Hon. Irord, Lt.-Col, Norfolk Art. Mil.

Hoole, F. W. Licut. 2nd West York Ride Tols.

Lumsilen, Henry, Capt. London Scottish Ride Vols.

ANNUAL.

Grace, Sheflield, Major h.-p. 86th Regt.
Erans, R. Ilarding, Capt. Joyal London Militia.

Greenwood, Frederich, It. Col. Gth West Yorh Rifle Tols.

Coles, Alfred, It..Col. 1st Surrey Rife Tols.

Osley, John S., Lt.-Col. 19th Iriddleses Ritle Vols.

Read, Philip, Captrin 19th Jidddleser Rifle Vols.

Perron, MI. B., Captain 2nd Middlesex Art. Vols.

Adair, A. S., Captain Finn. Royal Rilles. Btilne, IY., Maj.-Gen. Bengal Aring.

Conolly, Arthur, Licut., Bengal Staff
Forster, William, Tient. 60th Rifleg.

Clery, C. F., Captsin 32nd Regt.

Hay, W. E., Major, late Indian Amnj.

Tully, Thoma, Licut. 28th Mtiddlesex Rile Vols.

Llogd, N. Y., Lieut. 82nd Regt.

Read, C. E., Licut. R.N.

Boileau, C. H., Captain 61st Regt.

Hunt, Chas. 13., Licut. 4th Surreg Rille Vols.

Puckle, Alfred D., Iicut. London Scottish Rine Vols.

Fcilden, R. J., Col. late Coth Royal Rifles.

Hilton, J. WV. D., Lient. 3rd Hugears.

Hannen, G. G., Captain R.A.

Corps.

\section{ON ECONOMY OF FUEL IN SHIPS OF WAR.}

\section{By T. Syues Prideaux, Esq., C.F.}

Ir has always appeared to me that the question of "Economy of Fucl in Stcam Ships. of War" has nerer received that amount of attention to which the importance of the subject entitles it. All those considerations which render it so desirable to obtain stenm power on land for onr manufacturing ancether purposes, with the smallest possible expen. 
ditare of fuel, are increased in forco and leightened in importance when applicd to the case of ships which trarerse the occan. Fconomy of fuel in a ship of war confers the power of selecting ouc or more from a list of many adrantages. It is equiralent to a smaller, handicr, and cheaper ship, or to thicher armour and leavie: armament, or to higher speed, or lastly, but not least in ralne, to the capacity for remainings under steam for a longer period.

Supposing two rival powers with navies of cqual force, but that the ships composing the Nary of one were ablo to maintain their stations at sea without resorting to a conliug depôt twice as long as those of the other, who can fail to recogrnise in this facults an element of superiority that would, in the erent of war, find erer-rccurring opportunitics of exlibiting itself?

Imagine two ironclads of the largest size and armament, costing say $£ 300,000$ ench, and having stowage in their coal bunkers for 800 tons of coal, and that this quantity amounts, in the case of one, to cight dass' consumption, and in that of the other to sixteen, who can fail to recognise in the latter, such a much greater capacity for doing duts as a ship of war, that almost ans sum would be well expended on the former, to obtain the same cconomy of fucl? Were it requisite to constract her furnace bars and doors of silver to effect this object, the prico should be checrfully paid. Unforiunately, it must bo confessed that our own Navy is sadly behindhand in this clement of efficiency.

The comparison I have made of two sister ships, one of which burns only half as many coals as the other, is, I believe, by no means an exaggerated picture of the diminished consumption of coal per horsepower in steam ressels, which has actually taken place since my attention ras first directed to this subject twenty jears ago. At that period I pointed out that the consumption of coal in marine engines was excessive, and capable of being reduced one-half; but wy statements on that head prored unpalatible, and found little credence amongst the enginecring authorities of the day. I have lived, however, to see them verified, and also to come to the conclusion that they were so much within the mark as to be capable of being repeated, or in other words, that our consumption of coal per horse-power in marine cngines maj again be halied.

$\Delta$ s long ago as 18.5.1, at almost my first interview with Sir Baldwin Walker, who was then Comptroller of the Navy, I stated that Her Mrajesty's ships were burning twice the weight of coal per h.-p. that would be used in a not very clistant future, that all the knowledge was in existence to cnable this saring to be effected, and that it ought to be applicd at once. I have since had the satisfaction of sending Sir Baldwin an extract from the Naval Correspondent of the Times, showing that the economy predieted had been more than attained, and I was able to append a reference, with the motto, Litcich scripta manct, showing that the result had been effected by the precise channel pointed out by me in my treatise on Economy of Fuel, published in 1853 . In 1855 , after my return from the Baltic, I was so impressed with the waste of fucl and the inordinate heat of the stolie-holes I witnessed in the flect-the candles being melted in the Officer's' cabins 
in the gunboats - that I addressed a letter to the Admiralty offering to reluce the arcrage consumption of fuel one-lialf, and the temperature in the stoke-holes 20 $0^{\circ}$, but the offer was so distasteful to the Engineering Department, that they did not eren ronchsafe a reply.

In $1857 \mathrm{I}$ also offered, for the third time, to save 50 per cent. in the fucl expended per horse-power obtained, saying, "I state with confidence "that this amount of saring may be effected by the channels I have "indicated. In short, the question really at issue is whether a waste of " 50 per cent. of fuel is to be persisted in, for the sake of the personal " interests and feclings bound up with the present arrangements."

In Januars, 1859, I subnitted a memorandum to the Admiralty, from which I subjoin the following extract:- "For fire years past I "been labouring, in season and out of season, to inculcate the import"ance-nay, the absolute uccessity-of allowing a proper flane-space " (large enough for the most bituminous fuel likels to be used) between "the grate bars and the tubes, if anything approaching perfect com"bastion witl its concomitant absence of smoke is to be attained. In " tubular boilers as theg lare been, and I fear. I must say still are, " commonly constructed, the flame arising from the last foot or two feet " of bars, is extinguished by entering the tubes before its derelopment "is complete, producing smoke instead of heat. The necessity of pre"serving the products of combustion from coutact with metallic "surfaces till after inflammation is complete, to obtain perfect com"bustion appears to me most obvious, set it has been all but cntirely " overlooked in the construction of boilers up to the present time-tho "existing boilers in the Nary to wit."

The researches of the celebrited French chemist Recrinalt, have given us a far more accurate knowledge of the laws governing the amount of hent in stcam of different elasticities and temperatures, than was possessed in the the time of WVatt, so much so, that within very narrow limits of error, we may now be said to possess the necessary data for treating exhaustively the question of the steam power practically attainable by the combustion of a given weight of fuel.

The question of the economic production of steam-power naturally resolves itself into two perfectly distinct branches, viz., first, how to exiporate the greatest weight of water with a given weight of combustible, hinging on the structural arraugements and management of the furnace and boiler; and secondly; how to obtain the maximum mechanical effect from the steam raised, dependent upon the construction and mamagement of the engine. The frst branch being chicfly concerned with chemistry and physifs, the second with physics and mechanics.

To cvaporate the greatest weight of water from the fuel emploged involves two considerations:-First, the generating from that fuel the utmost amount of heat it is capable of rendering, to be accomplished by effecting perfect combustion in the furnace. Sccondly, the transference of the largest practicable proportion of this heat to the water in the boiler, to be attained by the judicions arrangement of its heating surface. The first, a question beset with complication; the second, one of comparatire simplicity. 
Coal is so much more extensirely used than any other combustible for the production of stean porver, that in so condensed an exposition of the subject as the present must necessarily be, it will be most profitable to restrict our remarks to its use.

At the outset of oar enquiry we aro confronted with the question, What propartion of the whole heat coal is capable of yielding, do we succeed in ntilising in raising steam, or, in other words, transferring to the water in the boiler?

After carefully investigating the subject, the conclusion at which I have arrived is, that we cannot assign to carbon a smaller heating: power than $9000^{\circ}$ centigrade, which is cquivalent to the capacity for evaporating fifteen times its own weight of water from $100^{\circ}$ Fahrenheit. The average duty obtainel in marine boilers at present must, I apprehend, be sct down at not more than $7 \frac{1}{2}$ lbs. of water craporated by $1 \mathrm{lb}$. of conl, or, in other words, we only obtain half the duty which theory assigus to the facl. Let us console ourselres for so hamiliating a result by the reflection, that this very large margin for waste is as encouraging to our future prospects as it is discreditable to our present practice.

The leat obtained from coal is evolved by the chemical nnion of the hydrogen and carbon of the coal with the oxygen of the atmosphere, forming with the forncr snbstance, water, and with the latter, carbonic acid, and just in proportion to the exactitude witl which we transform all the hydrogen of the combustible into water, and all its carbon into carbonic acid, without admitting any superfluous nir, will be the temperature produced, and (other conditions being equal) the amount of water evaporated.

Different coals vary in their component parts, and in the proportion of these to each other. Carbon and hydrogen, however, are the essential constituents of all as far as their heating capacities are concerned, and I shall assame as a convenient standard that 100 parts of coal consist of 80 parts of carbon and 5 of hydrogen, leaving out of view the other elementary substances which enter into their composition (consisting of oxygen, uitrogen, sulphur, and incombustible ashes, composed principally of sand and clas), as non-essential to the subject ander discassion. There is a convenience in assuming these proportions of 80 carbon and 5 hydrogen for the composition of coal, for since hydrogen farnishes, reight for weight, four times as much beat as carbon, the 5 parts of hydrogen will furnish 20 per cent. of the whole heat, and the 80 parts of carbon 80 per cent., being the same proportionate part of the heat as it forms by weight of the fael, and thus the heating power of coal, as a whole; many be treated as equiralent to an equal weight of carbon.

The hydrogen in coal exists in cliemical combination with carbon, and when heated withont the access of air, passes off with the carbon, with which it is combiner in the gascous form as carburetted hydrogen, a gas consisting of 1 part by weight of lygdrogen and 3 of carbon, being in fact the coal gas we use for illuminating purposes. 100 lbs., therefore, of coal containing 5 parts of hydrogen and 80 parts of carbon in the $100 \mathrm{lbs}$. wonld field $20 \mathrm{lbs}$, or 525 cubic fect of this gas, and $65 \mathrm{lbs}$. of solid carbon, or coke. 
As the 5 parts of hydrogen in coal gas furnish 20 parts of tho total heat of the coal, and the 15 parts of carbon 15 parts, the two combiued contain 35 per cent. of the total heating power of the combustible. But here I inust not omit to draw your attention to the important fact that if, through the defective regulation of the air supply of the furnace, yon cause half this gas to pass off up the chimney unburnt, the heat wasted is more than $17 \frac{1}{3}$ per cent., because the gas has robbed the furnace of the heat emplojed in its own rolatilisation or transformation from the solid into the gaseous form. 71 per cent. is by no means an vrer-estimate of the heat subtracted from the duty of the carbon by this process, and hence we arrive at the result that, in the case of a furnace so managed as to dissipate half the carburetted hydrogen unburint, the waste of finel through this channel alone reaches $25 \mathrm{per}$ cent. That this amount of waste does in practice often take place from this cause is unquestionable, since $I$ hare in numerous iustances witnessed this percentage of saving effected by simply altering the conditions gorerning the air-supply of the furnace daring the first fire minutes after coaling, the period at which, under the ordinary system of furnace mamagement, or rather mismainagement, this great waste of uuconsurued gas takes place. In short, I lawe rarely scen an instance where experiment did not prove that, with bituminous or north country coal, a saving of not less than two-thirds of this amount, or from 17 to 18 per cent. was obtainable by these rncans, so that I feel justitied in saying that in furnaces as construeted and fircd at present, i.e., with no provision for adaptingr the air supply to the clanging conditions and consequent varying requirements of the fucl, this waste of a large proportion of the gascons constituents of the coal must be regarded as the normal state of things, and inseparable from the rule, defective, and unintelligent systeru of furnace-management pursued.

Although, as a general rule, the combustion of the carbon of the fuel is effected without the large proportion of waste attendant upon that of its gascons constituents, yet occasionally-in such a case, for instance, ats oue of which we hare recently hicord, where, in the Southern Pacific, the flames proceediver from the top of the funncl of one of Her Maijesty"s ships at night were actually mistaken for an eruption from a rolcano in one of the peals of the Andes-it ereat waste of curbon occurs. Such a state of things as this, howerer, cin only exist with most defective lurnace arrangements, involving it really frightitiul sacritice of fucl.

I will endearour to deseribe the conditions under which alone I consider such an occurrence as described to be possible. The flame emitted does not extend from the fumace through the flues to the funuel be?.d, as many suppose, but is produced by carbonic oxide gatas (generated in the furnace throngh deficiency of the air supply), passingr ofl at such a hight temperature as to preserve the temperature vecessary for ignition, after mising with the $2 \frac{1}{2}$ rolumes of atmospheric air required to furnish the oxygen needful for its transformation into cirsbonic acid. Now, since an atom of carbon, in combining with one atom of oxyocn, and becoming carbonic oxide, only yiclds one-third of its leating power, the rymaining two-thirds being set frec upon its combining with the second equivalent of oxygen, and becoming carbonic 
acid, it follows that $t$ wo-thirds of the heating power of all the carbon passing off as carbonic oxide is wasted.

Even this statcment does not adequately represent the frightful sacrifice of heating power, of which flimes passing of at the funnel head are the sign; for small as mas be the proportion of the heating power of the fucl developed in the furnace, of this small proportion, an unusually large part is wastefully dissipated into the atmosphere, as is shown by the high temperature of the gases issuing from the funnel, such high temperature being the result of the diminished subtraction of their heat by the surface of the tubes, consequent upon the latter being coated with soot. Unless there be something more than ordivarily faulty, either in the construction of the furnace, or the mode of firing pursucd, the coating of the tubes with soot may be regarded as the uecessary preedent to the exhibition of flame at the funuel-head, as in fact begetting the conditions under which it occurs. A deposition of soot on the interior of the tubes, simultaneously diminishes the draft, and in a still greater ratio the stean generated. Heavier firing is resorted to to keep up steam, with the effect of aggravating the previously existing erils. Flame makes its appearance at the top of the funuel, and a vicious circle of eril consequences is produced which mutually re-act upon and aggrarate cach ofher.

The wiste of a larege proportion of the coal gias or carburetted hydrogeu con ained in the fuel, during sas the first third, or first five minutes of the coaling interval, which ordinarily takes place under the present system of furnace management, by no means pre-snpposes such conditions in the arrangement:; and working of the furnace, as would subsequently lead to the dissipation of carbon as carbonic oxide. The fatal sign of flame at the funnel head, howerer,-announcing as it docs a thick layer of ignited carbon on the bars, and an iusulficient airsupply,-may be accepted as indicatire of conditions beingr present in the furnace, which must have been productive of a more than average waste of carburetted hyclrogen at an earlier period.

Great as are the evils which we have been reviewing, proceding from a deficient air supply, they are rivalled, and, perhaps, having regard to its greater frequencs (during the latter portion of the coaling interval), excecded in amount as a whole, by the opposite fault of too much air entering the furnace. The excess of air acts prejudicially, not by interfering with the perfect combustion of the carbon, none of which under these altered conditions can escape transformation into carbonic acid, but by diluting the temperature of the furnace by the admixtare of cold air, which, after receiving a large accession of temperature, passes off through the funnel, robbing the furnace of heat that should haro been employed in raising stenm. All good firemen are awake to the cril consequences of allowing their fire to burn throngh at the back, admitting a free ingress of air, or the still more fatal results of perforations in the door or bridge. Let us analyse the conditions under which these evil consequeaces ensue, and the causes on which they depend:-

One hundred pounds of coal require, in order to obtain the equiralent of oxygen necessary for its perfect combustion (or the transformation of all its hychogen into water aud all its carbon into carbonic acid) 
15,000 cubic fect of air, and the temperature resnlting mas, to spcak in round numbers, be set down at $1,200^{\circ}$. No such exact adjustment of the air-supply is possible in wurking a furmace, and there are reasons why, in practice, a better result is obtained by admitting an incrensed quantits, sas firl wore than the amount required to firmish the cxact combining equivalent of oxyern. Assuming, therefore, the almision of $y$ rd more, or 20,000 cubie fect, we get a temparature of 3150 , of which, taking the temparature of the gases when thes leave the heating surfice of the boiler aud colder the funnel at $600^{\prime}, 81 \mathrm{pcr}$ ceut. is absorbed by the heating surface of the boiler, and profitably employed. If instead of 20,000 feet twice the quantit 5 , or 10,000 fect, coter the furnace, ve only get a temperature of $1575^{\circ}$; and supposing the temperature of the grases entering the stack to be the same, viz. $600^{\circ}$, we only get 62 per cent. absorbed by the leating surfice and performing tho duty of ralisiner steam. In reality, however, since twice the volume of gas traverses the flues in the sane time, it must pass over the heating surface at twice the velocity. The area of the lieating smeface therefure becomes halved in proportion to the quantity of gas pisssing, and, as a consequeuee, the products of combustion will pass off at a higher temperature, so that in reality less than 62 per cent. will be absorbed.

'Thus, parndoxical as at first sight it mily appear, when a climinished temperature of the products of combustion is camsed by their rolume being increased by an excess of cold air entering the furmace, the lower their temperature in the furnace, the higher will be the temperature at which they will pass ofir through the fuuncl, still further marruifying the wiste of fiel inviably attendant upon the existence of conditions which diminish the temperature by facilitating the entrance of superfluous air.

Our inquiries have landed us at the conclusion, that the more 1a:rrowly the conditious attendint upon the worling of a furnace are investigated, and the mo: closely the duty performed is compared with these conditions, the more manifest does it become that the first of the two bianches or divisions into which the question of the ceonomic production of steam power naturally resolves itself, viz., " How to evaporate the greatest weight of witer with a given weight of combustible?" i; for all practical purposes almost synonymons with the question, "How to ndmit the right quautity of air to the furnace?" $A$ competent leating surface must, as it matter of course, be prorided; but it is not in respect to the absorption of heat, but in respect to its generation, that our present practice is so sadly in arrear, and that such a vast scope for improvement is risible.

How are we to realise in practice this all-importaut and indispensable condition to cconomic fumace nutnagement, the due adjustuncut of the air-supple, thit is, the supply of such in cunatity as it reluele, and so distributed ats to priom, ats to convert all the hydrofen of the fucl into water, and all the carbon into carbonic acid, with the admixture of the smallest possible quantity of surplus air? Howerer difficult the tas! may be, it is nevertheless most certain that by how nuch wo devinte from the correct gunntity; cither more or less, by" so duuch do we fill short of "generating from the combustible, the utmost anount of" Jeat it is ciprible of furnishinge," for the 
laws of chemical affinity are unchangeable and ubiquitous. In short, this danger of erring on either side, may be said to be the Scylla and Charybdis to which royagers in search of perfection in furnace manage. ment are exposed, and safety is only to be attained by studying the landmarks and bearings so carefully as to be able to steer with con. fidence a middle course.

'The sapply of air which enters a furnace depends upon the ratio existing between the pull exerted by its chimney or stack and the obstruction caused by the lajer of fuel on the grate-bars, and a more ov. less confined ashrit. The force of the pull, or suction, exerted by the stack, is the difference in weirght between the column of heated gas it contains and a similar column of air at the temperature of the atmosphere. The higher the temperature and the taller the stack, the greater the force of the draft, and vice verist. The great practical diffienlty which stands in the way of obtaining the regular flow of the right quantity of air into the furmece, is the fact that the demand is not a coistant, but a rarying, quantity. Wrere the same conditions alwajs present in the interior of the furnace, that is to say, the same thichness of fuel on the grate bars, and the various layers of this fuel at similar stages of combustion, so as to cause the supply of air demanded by the wants of the fuel to be uniform, then, the average rarefaction or draft in the stack being once attained, at steady supply would enter the furnace, proportionate to the thickness and closeness of the layer of fuel, the area of the grate-bar openings, and the free ingress of air to the ashpit, whicl, once adjusted, the equable and ccononic worleing of the furnace would be secured. Unfortunately howerer, for the cause of cconomy of fucl, the reverse is the case; not ouly are the requirements of the furnace not nniform, but thes fluctuate within vers wide limits, whilst the cvil results in waste of fucl which ensue, are angrawated by the fact that the furnace's massisted power of supplying. itself, varies in an inverse ratio to its requirements, beiner lenst when these are greatest.

Assume a coalingr interval of 15 minutes, and that towards its end the carburetted hydrogen having passed off, a layer of ignited carbon alone is left on the bars through which the current of air has gradually worn for itself a series of channels or perforntions, till their united area is more than sufficient to admit the right quantity of air under the existing amount of draft. Let us then examine the condition of the same lurnace a few minutes later, after the act of coaling has taken place, and we shall find a thicker layer of fuel on the bars, the channels for the passage of air which previously existed in the thinner layer, obliterated, and the temperature of the furnace greatly lowered by the abstraction of leat consequent upon the introduction of the charge of cold fuel, and the rolatilization of its gas going forward. 'Thus the diminished temperature in the stack diminishes the draft at the period when the resistance offered by the fuel to the passage of air is greatest, and the demands of the furnace for air is at its highest point, in cousequence of the larere quantity of oxygen required for the ignition of the carbundted hyclrogen gas now in comse of rapid evolution. As the necessaly sequel to these conditions, the gals grenerated passes 
off unburnt, worse than simply wasted, because it has abstracted a portion of beat from the ignitcd carbon in undergoing trausformation into the gascous form. We here get an explanation of the fact that more heat is practically obtained in some kinds of furnaces from coke, or, in other words, coal deprived of $\frac{1}{3}$ rd part by weight of that portion of its combustible matter which is richest in lienting material, than from coal in its pure state. From the same causc also, viz., defectire furnace management, the commercial value of coal is often in an inverse ratio to the quantity of its bituminous constituents and heat-giring power, were proper means enployed to make then practically arailable.

In short, under the present system of furnace management, the function of the furnace as an agent for raising stcam mas be said to be almost cutirely suspended after each coalingr interval, aud only gradually regained, the furnace virtnally assuming the office of a retort for the manufactare of gas, but with this difference in the result, that the gas which in the latter case is carefully preserved as a valuable commodity, is here despatched uncousumed up the chinner, carrying off at the same time the heat stolen from the carbon in eflecting its volatilizatiou.

Can a doubt be entertained of the wisdom and desirability of burning this gas instend of wasting it-of filling the furnace with flame instead of smoke- of causing the generation of steam to proceed with additional rapidity immediately after coaling, instend of being all but suspended?

Now all that is required to croke this transformation is to supply the gas with ten imes its own measure of atmospheric air, and (except in a few exceptional cases of badls constructed furmaces) it will require no further solicitation to burst into flame. Why is this not universally done? A carious chapter of human crror is unfolded by the answer. When apertures of the necessary size to admit the recuuisite supply of air were arranged to open into the furnace above the fuel, nutwithstauding the smoke aud grases were courerted into flame, it was found that the production of steam was diminished from 25 to 30 per cent., and ouly when there was sufficiently anple boiler power to allow of henvier firing, and burning from 25 to 30 per cent. more coal, could the previous supply of steam be obtained. The most extensive experience, and the most exact experiments, alike conenr in establishiug tho accuracy of these figmes.

The analysis we have made of the varying conditions of the furuace at different periods of the coaling interval, and of the sequence of chemical changes of which these varyiug conditions are productive, not only enables us to explain how, and why, this great diminution in the creneration of steam occurs, but places us on a rantage ground of knowledge from which the necessity of such a result is foreseen. Su dark, howerer, has been the pall of ignomanee that has rested on the subject, in such mystery lave the chemical operations of our furmaces been sbronded, that for half a century each ycar has secn the adrent. of some new scheme, identical with its predecessors in the folls of sllowing a coustant supply of air to enter the furnace above the fuel, but rainly pretending to elude the evil cousequences iuseparable from such a practice, by tivial alterations in non-esscutial details. Strange to say; the persistence of these eril results, after the shape of the oritices 
for the almission of air lad been changed from round to square, and from square to oblong; the weterial from firebrick to cast-iron, and from cast-iron to wrought; the position from the door to the brilge, and from the bridge to the flucs; instead of opening the eyes of the experimenters to the common ground of failure inlerent in all their attenipts, caused them to adopt as an indisputable masim the dorgma "that smoke can only be burnt at the cost of fucl," a doctrive most correctly" describing the result of the faulty expedients they resorted to for obtaining this object, but widely the rererse of truth when cnunciated as a general law.

When a continuous stream of air is allorred to pass into the furnace above the fuel, about six times the required quantity of air enters and mingles with the products of combnstion, and the great resulting waste of fuel, amounting to from 2.5 to 30 jer cent., will be seen to be a necessary consequence, by all who have followed the exposition I have giren of the great reduction in temperature inseparably atteudant upon the entrance of a large surplus body of atir into the furnace.

The fact is, the policy of admitting air above the fire, is gorerned by the rery simple liw that no more should be admitted than is required to furnish the quota of oxygen necessars for the perfect oxyctation of the gases rising from the fuel at the moment. The quantity required is grentest after conling, gradnally diminishes in amomt throughont the space of about firc or six minutes, and then eeascs altogether, the increasing draft in the stack lhaving become suflicient to supply through the grato bars the diminished and diminishing wants of the fucl.

To sccure the entrance of the required amount of air and no more, to consure that this supply shall vary in quantity pair passu with the wants of the fuel, that is to say be greatest afier coaling, gandually diminish in amount throughout a space of about five or six minutes, and then cense altorrether, it is indispensable that the recrulation of the feed of air be placed under the control of automatic mechanisu, which not ouly fir surpasses in regularity as to time, and equability as to motion, tho limits at trinable by the utmost wat chfulness of man, but is fice from the liability to the omissious from negligence, insepar:ble from human superintendence, especially where, as in the present instance, that superintendence would bo of an exceptionally monotonous and wearisome character, and carried on in an atmosphere most oppressire and exlausting.

The front of evers furmace shonld be supplied with air passages of an area cqual to thic adnission of the largest required amount of air, and opening into the furnace by sinall perforations or grating for fincls dividing and heating the air, but commmicating exteriorly with one common mouth fitted with a valve closing automatically in any desired period of time. 'This valre is to be thrown wide open upon closing the door after conling, when it immediately begins to close grachally, supplying the fumace with the great desideratim, a graduilly diminishing feed of air throughout the five or six minutes' intervil for which it is adjusted.

To illustrate nyy views on the subject in a practical form, I liave placed before you on the table an appanatus which I consider fulfils the required condrions. Without admitting any superfluous air it conrerts 
into flame the carburetted hydrogen rapidly erolyed after conling (and wasted uuder the present unintelligent system of furnace manarement, apparently as a matter of course). The cconomy resulting is from 8 to 10 per cent. with best Wclsh, and from 16 to $2 f$ per cent. with bituminous coal, and since the apparatus presents no objectionable feature to counterbalance these advantanes, but on the contrary increases the steam supply, diminishes the temperitture of the stoke-hole, prevents snoke, and increases the durability of the sails, I venture to predict that, when the incrcdulity of ignoranec as to possible saring of fucl, which now flourishes, becomes replaced by an intelligent insight into furnace, operations, its use will become universal, and it will be regarded as being as indispensable an adjunct to the furnace, as the governor now is to the engine.

Prinfidx's Fucl Ecosomisri, or Adtomitic Appinitus ror Rrgulatixg the Ami-Supply of Funsaces.

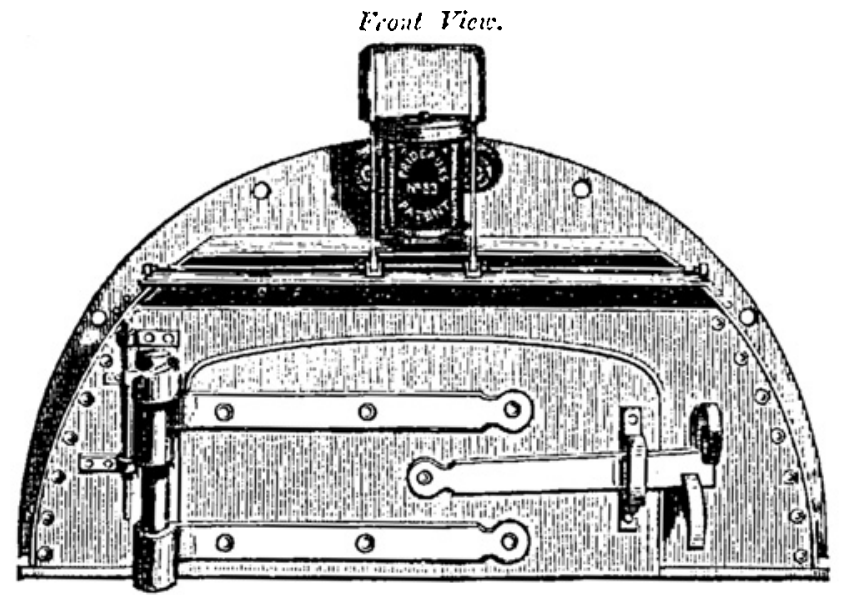

Back Iiew, opening on interior of Furnace.

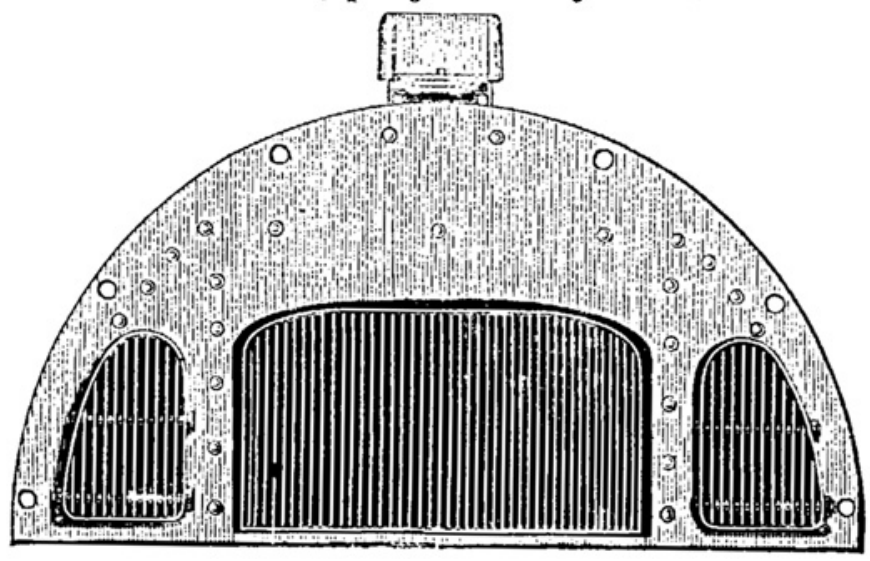


Diffenext Sistejs of Fundace Masagemext Cojpaled.

\begin{tabular}{|c|c|c|c|}
\hline \multirow{2}{*}{ Systems. } & \multirow{2}{*}{ Results. } & \multicolumn{2}{|c|}{ Coal burut. } \\
\hline & & $\begin{array}{c}\text { Bitu- } \\
\text { ninous. }\end{array}$ & Welsh. \\
\hline $\begin{array}{l}\text { Old, and still precailing. } \\
\text { No air uddmitied abore tire. }\end{array}$ & $\begin{array}{l}\text { Suows: } \\
\text { Hot furnace door. }\end{array}$ & 100 & 90 \\
\hline $\begin{array}{l}\text { Aninally tried under a new alias } \\
\text { for fifty years past, but alicays } \\
\text { abaindoined. }\end{array}$ & & & \\
\hline $\begin{array}{c}\text { Constaut admisiou of air aborc } \\
\text { fire. }\end{array}$ & $\begin{array}{l}\text { No Sront. } \\
\text { Diminished steam Eupply. }\end{array}$ & 130 & 110 \\
\hline $\begin{array}{c}\text { Plan of the fuluie. } \\
\text { Sir udmitted and cut off by Auto. } \\
\text { matic Air Regulator. }\end{array}$ & $\begin{array}{l}\text { No Ssrokr. } \\
\text { Increnscl steam supply. } \\
\text { Cold fumbace door. }\end{array}$ & 80 & 80 \\
\hline
\end{tabular}

To discard the use of selfacting mechinism for closing the apertures for the adnission of air, and elect to effect this olject by hand in preference, is a step as retrograde as going back in the construction of the stearn-cngiue to the era of Humphrey I'otter, and stationing a boy to open and shut the ralve between the eylinder and the condenser. Adequately to appreciate the obtnseness and stolidity involved in the adoption of this oft-tried and abandonect system of shutting by land, when self-acting mechanism invented specially for the lurpose is in existence, so perfect in its action as to leave nothing to be desired, we have ouly to consider that, even supposing a man were detailed for the purpuse, whose sole duty would be to stand witl at watch in his hand to shut off the air suppls at the right moment, twice the proper yuantity of air mould cuter the furnace; whilst how hopeless of attainment is even an approximation to such a result, except in an experiment, all having any practical lnowledge of stolicrs, stokiug, and stokc-boles, cain decide for themselves.

I will now draw your attention for a few moments to a subject by no means inoperative in relation to consumption of fuel, I allude to the temperiture of the stoke-hole. However perlect we may make our furnace arrangements, wo cannot withdraw omselves from a certain amount of dependence upon the intelligence and attenticeness of ond firemen. And very sure I am that the loss cslransting we render their occupation, and the more comfortable we make the place in which thes perform their duties, the greater will be the amount of attention the furnaces will be likely to receive. Indeed I think it would be to be regretted were it otherwise, so very little regard, according to ms experience, does the humanitarian side of the question command. 'l'here cannot be two opinions but that far greater stmin is malde on the 
physical energies of a fireman by working in a temperature of $120^{\circ}$ than would be occasioned by performing the same dutics in an atmosphere of $100^{\circ}$. In fact, the depression of tho vital powers that ensues in tropical climates, where the heat of the stoke-hole often mounts up to $135^{\circ}$, is a fertile source of clisease, and loss of life. Now experience anthorises my saying that there is hardly a ship in Her Majesty's Navy in which the temperature of the stoke-hole might not easily be reduced from $20^{\circ}$ to $30^{\circ}$.

The same apparatus which regulates the air-feed forms a most efficient agent for preventing the radiation of beat into the stoke-hole, from the fire loor and front of the furnace, never becoming so hot but that yon ean place the back of your hand against it. As to tho other grent source of heat, the smoke-box doors, they should be fitted with what I have designated "non-condneting shields." These are made of tiv, are light, easily applied, and productire of no inconvenience of any hind, and, at the same time, are so effective in resisting the passage of heat, that, in conjunction with the air-feeding apparatus, they cause the stobe-hole to be on the average at least $24^{\circ}$ cooler.

As an adrocate of the comfort of the fireman, I $\mathrm{am}$ glad to be able to adduce in support of iny own opinion that of Staff Commander Balliston, of the "Flfin," who, in his official report, says, "I cannot "speak too highly of the smoke-box doors supplied for trial. They "are simple, and ensily applied to all steam vesscls, neither do I con" sider them the least in the way, as they are fastened on to the pre"sent doors, and can be taken down or put up at pleasure.

"I consider their merits are even better than the cnclosed report of " the temperatures taken with the doors on now, and the correspond"ing account of the temperature taken last year when they were not " supplied. My reason for saying so is, that, from the confined space "of the stoke-hole, the thermometer is obliged to be placed in a corner " out of the way of the stokers, where the hent must necessarily accu" mulate. The patent doors are so cool that you may place your hand " upon them without feeling the least warmth; the same may also be " said of the front of the pitent fre-doos:

"The thermometer, when placed on the patent smoke-door, showed " $92^{\circ}$; and when the door was taken down, and it was bung on the "flue-door, it immediately went up to $116^{\circ}$, thereby showing a differ" ence in the temperatnro of $24^{\circ}$, and that in a place where the stokers " have to work."

My attention was first called to the great heat firemen are often sub. jected to in stoke-holes in the following manner:-My first experiment wis made by permission of the Admiralty, at my own expense, in Portsmonth Docksard. A thermometer with its bulb in contact with the face of my fire-door nercr marked nore than $64^{\circ}$, whilst the adjoining door of the same marine boiler was sometimes red with heat. The contrast seemed to strike the Naval Officers who witnessed it as something marrellous. The first lieutenant of a steamer just returned from the West Indies observed to me, "Mr. Prideans, your apparatus "will lead to a considerable saving of fuel. I don't mean by producing " more perfect combustion, which it may or may not do, for I have not 
"tried it; but it will save fuel by cnabline the nen to tend the fires "with more confort. $M y$ experience is, that a high temperature in "the furnace-room always tclls its tale in the consumption of fuel; fol. " whaterer" people may think, careful stoking does not take place in an "atmosphere of $140^{\circ}$, and it is not in human nature that it should."

IIe also informed me that when commanding the "Ball Dog" in the Chauncl the summer before, he had had several iustances of stokers fainting, and being obliged to be hoisted up on deck by tackle, to be revired by the fresh air. The thermometer in the stoke-hole indicated $140^{\circ}$, and the firemen could not landle their implements without binding cloths round the handles. It seemed to me monstrous that men should be tortured in this way if it could be prevented, and so I devised these non-conducting shields; and it should not be orerlooked that, in addition to kecping down the heat of the stoke-hole, they prevent a waste of draft power. I determined from the first never to make an article of profit of them, and I have always offered to supply owners of steam ressels with them at cost price.

In treating of so important a guestion as the cconomic production of steam power within limits so inadequate to do justice to so extensire a subject, that some departments must vecessarily be left comparatively in shadow, I have felt I should best consult your wishes to acquire, and mine to impart, useful information, by cudcarouring to emphasize those points at present least understood and most neglected. In endearouring to fulfil this intention, I find I have already oceupied so much of your time on the right mauagement of the furnase, that it will be impossible for me to advert in more than general terms to the structural details of the boiler and the engine. It must suffice to say, that in the past, attention has in the former, been directed too exclusirely to the amount of grate, bar, and heating surface, to the comparative neglect of securiug the due circulation of the water, and an adequate amount of what $I$ haro designated flame space, that is, a sufficient distance between the end of the bars, and the beginning of the tubes, to admit of the completion of the formation of flame before the products of combustion enter the latter.

If you take a piece of wire gauze, and insert it across the middle of the flame from a gas burner, or candle, you will fincl that the portion of the flame abore the gauze becomes immediately extinguished. We hare flame below the gauze but smoke above. The inflammable mixture of air and gas, which would otherwise form the upper portion of the flame, is cooled down by contact with the wire net work below the point of ignition. What the wire gauze does in the experiment with the flame of a gaslight, viz., prevent combustion by cooling the mixture of air and gas below the point of ignition, the surface of the boiler tubes (kept comparatively cool by contact with water) effect with the gases rising from the furnace, and hence maste of fuel takes place as a matter of necessity, where the distance from the end of the furnace bars to the begiming of the tubes, is not sufficient to admit of the completion of the development of the flame; the gases which otherwise would tare formed flame, passing of as smoke, or being deposited as soot. 
Figr. 1.

Scalc !" to foot.

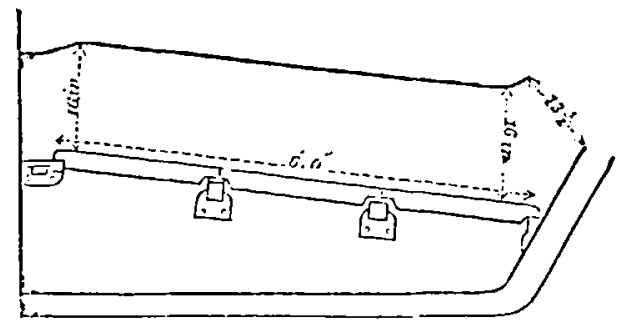

A few days ago, sorting orer some papers, I came on a tracing (Fig. 1) endorsed "order declined," which forcibly illustrates how little the necessity for a flame-space has been understood up to a comparatively recent period. It was sent to me by a firm on the Thames as a guide for making a set of my furmace doors for a steamer in process of building. I wrote back suggesting that 6 inches should bo taken off the bars, and 6 inches added to the flue, and the crown of the furnace raised at the back, and stated that, notwithstanding the tabes wonld be shortencd 6 inches, I would guaranteo the furnace should make more steam, and burn a very mueh smaller quantity of coal. I was told in reply that they had been obliged to make the most of the limited space at their disposal, and requested to procecd with making the doors. This, howerer, I declined to do, assigning as a reasou that the proportions of the boiler were so radically bad, that nothing but disappointment and discredit to all concerned could attend on its construction as designed.

Now in this case the preralent faults in boiler construction are carried to such an extreme of baduess that I doubt if any of you erer saw such a boiler at work, for it would fail so utterly in generating stcam that I imagine, after a short trial, it would be thrown aside as worthless. You will observe there is absolutely no prorision for a flame-space, and, as a necessary consequence, the heated gas coming at once in contact with the cold tubes, is cooled down below the point of ignition, and instead of forming flame to raise stearm, produces soot to coat the tules. The prevention of smoke in such a furnaco is a physical inpossibility and the waste of fuel enormous.

Fig. 2.

Figt. 2 is a sketch of the furnaces of H.Mr.S. "Princess Royal." This is a great adrance upon the preceding, for this is a workable furnace. Nerertheless the prevalent faults above alluded to, are only diminished, not removed. 'l'he bars are too long, and the flame-space much too short and narrow, to obtain the best results even with Welsh coal, whilst were bituminous coal used, swoke, with its attendant great waste of fuel, would crisue, especially when steaming at full specd. Since a boiler with a flame-space of suficient dimensions to allow of the inflammation of all the gas from bituminous conl, is perfectly well adapted to burn 
Welsh coal, I think it is obvious that all the boilers for the Navy shonld be so constructed. In this case, eren when supplied with all

Fig. 2.

1 " to foot.

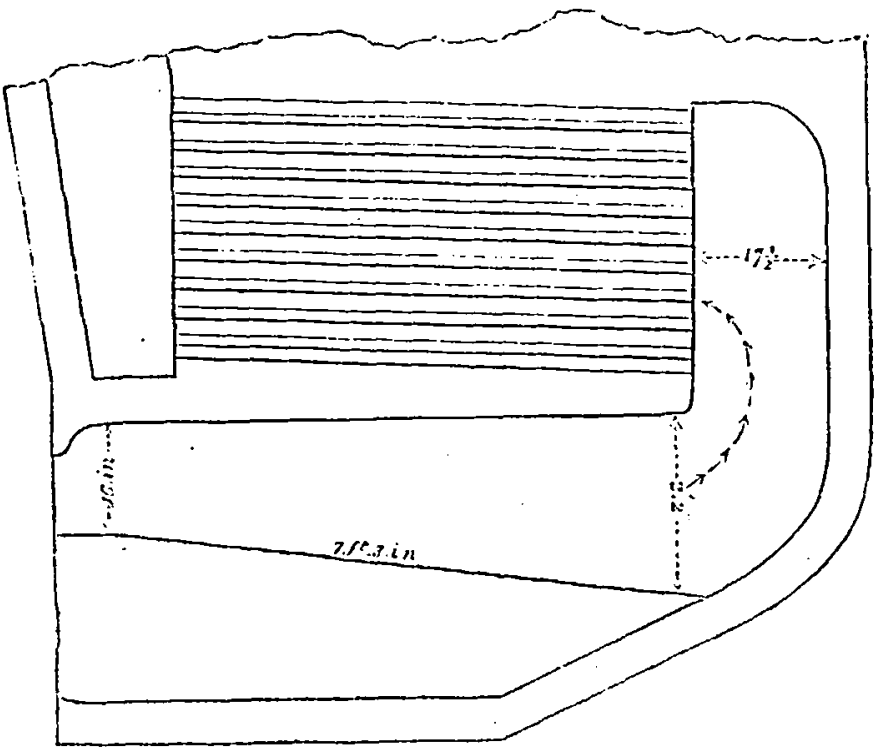

bituminous coal, which must occasionally happen in time of war, smoke could always be prevented. T hardly know a sabject on which so great and wide-spread a misapprehension exists, as that entertained rith regard to furnaces making smoke. If the llame-space of a furnace be not sufficiently roomy to admit of the full development of the flame, the prevention of smoke is a plyssical impossibility, but if the Hame-space be sufticient, nothing can be easier. A few holes in the door or bridge, or the furnace-door left ajar, are sufficient to prevent smoke. But such, or any mode of preventing smoke by the admission of a continuons supply of air abore the fire, necessitates 30 per cent. more coal being burte to obtain the same supply of steam. 'Ihis it is which has im. parted to the nuisance its vitality, and not the existence of any difficulty in the attainment of the object itself.

\section{Fig. 3.}

Fig. 3 embodies my views of what the proportions of the existing type of a naval boiler should be. You will observe it affords ample space for the fall development of the flame of the most bituminous coal before the products of combustion reach tho tubes, and it might be fed entirely with bitnminous coal without an atom of smoke being visible, whilst it would give better results in regard to economy than any naval boiler of the kind it has been my lot to meet with. It possesses a novelty in a bridgo $(a)$. of firebrick which spans the fue, 
with its under side level with the crown of the furnace. By pre. renting the current of beated gases taking so short a curro as would othermise be tho case, it materially contributes to their more equable diffusion through the tubes, remedying the fitult at present complained

Fig. 3.

$\frac{1}{3}$ " to foot.

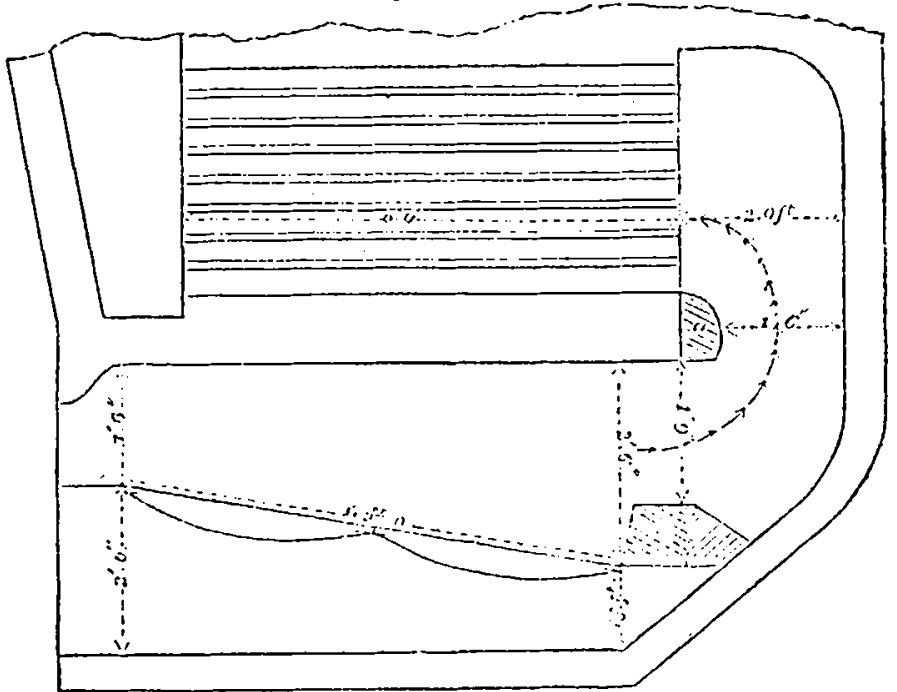

of, that the inajor porion passes through the lower tubes, leaving bat little to find its way through the higler, which is in reality tantamount to a diminution of the licating surface. :

Before quitting the first branch of our cuquirs, riz., "How to craporate the greatesi weight of water with a given weight of fuel linging on the structural arrangements and management of the furuace and hoiler," I am desirnus of bringing prominently under your rotice the fact, that since the office of the boiler (including the furnace) legins and ends with the eraporation of water, the proper way to test the rork it performs, is to measure the quantity of water it evaporates, by fitting cvery boiler with a waler meter, instead of cstimating its tuty in the rery rague and unsatisfactory mode in usc at present, riz., by the performance of the ship it scrves to propel, thus subjecting the

* In 1857 I made an ofer to the Admiralty to improre the furnaces of II.Mr.S. "I Injerieuse," suyin I could do so rely inexpensirely, whilst they could be restored to their previous form if thought desirable; that this mould not libels be the csec, as the altcration I should makre rould not be experiments, but founded on a knowledge of the subject, aequired by haring for ecren years past made the espcinlitice of furnaces almost exclusirely the object of $\mathrm{ms}$ study, in addlition to which, during the last two years I bad had the experience of adopting rily autowatic furvace.door to 609 furnaces of the most raried claracter, adding, "shenerer sn opportunity is afforded me, I elall be liapny to give the country the benefit of my long study and crperience on thiz subject; and I unlesitatingls ofirm, that hoilers mas be con-

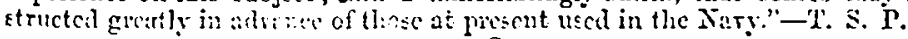

vol. Xir. 
results to all the uncertainty inseparable from a varicty of contingences such as defects in packing of pistons, in ralves, in bearings, in condenser, or other portions of the engine, and the ricissitudes of winds, tides, carrents, and sea, and the state of the ship's bottom, propeller; $\& c .$, \&c., the effects being to import such an amount of uncertainty into the results, that the formation of positive conclnsions and com. parisons is rendered impossible.

In carrying out scientific experiments, the first thing considered is, how best to eliminate sources of error by securing as far as possible the existence of similar conditions during cach experiment of a series, for thus only can reliable results be obtaincel. In their experiments on "Baxter's mixture," the Admiralty had put to sca in search of variable conditions, and after being at work in the "Lucifer" and "Urgent" for three years, had appa:ently failed to arrive at any nseful or decisive conclusion. In fact, I do not suppose they have added one grain of positive knowledge to our previous stock. Now had they put to me in a definite form the question they wanted solved, I would hare under. taken to have giren them an answer in three wecks instead of three years, and one which no subsequent amount of experimenting would ever have invalidated. 'I'he probability, however, is, that I conld have giren them an answer without experimentiner at all. As Naval Officers, what would you think of sending a gun to sea to test the accuricy of anew mode of rifling, and determine the target fignre? Now to a c'vemist, testing the value of a fucl by the locomotive performance of a ship, which means measuring the results at the tail-cnd of a set of variable conditions, was equally absurd. It was lamentable to sce such a want of intelligence exhibited in the conduct of public affairs, for it not only caused.a great waste of monef, but discredited the mation in the cyes of foreigu states.

The first step to progress, or rather an indispensable prelininary to taking the first step, is an accurate knowledge of our existing position, and it always has been my opinion that what I cannot but regard as the present highly unsatisfictory amount of coal burnt, to power obtained, is greatly to bo attribated to our habitually nerrlecting to determine by exact measurement, the actual work performed by the facl in water eraporated. Many years ago I took considerable troublo to induce the Admiralty to fit the boilers of all Her Majesty's ships with "water-meters," and kecp a record of the duty performed in weight of water cvaporated, for coal expended, believing the adoption of such a system could not fail to be ultimately productive of a greatly increased cconomy of fuel, but my efforts were not successful.

In reviewing the present state of the question of cconomy of fuel as a whole, $I$ confess the point which presents itsclf most forcibly to my mind, both from the waste it entails, and the degree in which its existence is overlooked, is the circumstance that in the management of our furnaces we make no provision for the widely different conditions as to air supply, which ought to prevail, as more or less timo has clapsed after coaling, involving the more or less rapid erolntiou of gas, or coke alone remaining to undergo combnstion.

'The secein bluscil of our" subject, "How to obtain the maximum 
mechanical effect from a given quantity of steam," dependent upon the construction and management of the engine, is, no doubt, a far more attractire subject for cuquiry than furnace-managrement, and one which commands a far greater annount of attention, and on some future occasion I may perhaps have the pleasure of presenting you with some analysis of its details. For the present I must content myself with saying in general terms that a very general agreement now exists as to the channel through which increased economs is to be sought, riz., by increasing the extent to which the steam is used expansively, through employing steam of higher pressure, and applying heat to the surface of the cylinder. A great increase in economy has been effected by travelling on this road, and I camnot donbt bot that it may be pursued still further with adrantage. In my treatise on "Economy of Fuel," published in February, 1853, I gave an estimate of the theoretic capabilitics of a stean-engine working at $90 \mathrm{lbs}$. pressure, and cutting off at onesixth, with the exterior of the cylinder preserved at the same temperature as the boiler, observing "the time will come when it will be quite an exceptional case for an engine to be worked at a lower pressure, or at a lower gride of expansion than this, for the simple reason that there is nothing to prerent this degree being generally used, and, therefore, to employ less will be considered as sacrificing cconomy without an object." At this period the general pressure employed in the Navy was 10 lbs., whilst there was not a single steamer afloat provided with any appliauce for applying heat to the cylinder.

Shortly after a consultation was held by desire of the Admiralty, at which it was decided that a cousiderable increase, I think to 26 lbs., should take place, and I was informed by a gentleman present that my book, which had then just appeared, rras quoted in support of the opinion that a much higher pressure might be adopted with perfect safety and great advantage.

From that period to this the pressure has gradually crept up till from 45 to 50, and eren 60 lbs. pressure is now not unfrequently used in marine boilers, and $I$ an quite satisfied this progressire advance will continue till the pressure of $90 \mathrm{lbs}$. is reached, for the simple rcason as I then stated, "that there is nothing to prevent this pressure being generally used, and, therefore, to employ less will be looked upon as salcrificing economy without an object."

I do not beliere, however, that we shall rest at 90 lbs. Other conditions being equal, the higher the pressure the greater the economy, but as we mount upwards in pressure, certain impediments, certain drawbacks present themselves. Now locomotive enginecrs bcing shut out from the advantages of condensation, have had erery inducement to increase their pressure till some barrier was encountered which rendered further adrance no longer adrantageous, and I find they have settled down to working with from $120 \mathrm{lbs}$. to $140 \mathrm{lbs}$. on the guage, or, in other words, using steam of from 9 to $10 \frac{1}{3}$ atmospheres, and I have no doubt but that in marine engines we shall nltimately come to much the samo practice. Could I afford the luxury of a steam yacht, I should certainly arrange to work with stcam of 9 atmospheres, and cut off at $-\frac{1}{10}$, and by combining with this degree of pressare and expension in$\geq$ A 2 
creased cconomy of fuel by the use of my automatic apparat us for regulating the air supply, I should expect to attain an economy of athout $1 \mathrm{lb}$. of conl per indicated horse-power per hour. If I live a few rears louger, I belicve I shall see this derrec of econoniy realised, aud I cho not hesitate to give the opinion that when we haro arrived at this point, re shall have nearly reached the utmost limits which the nature of the subject renders practically attainable.

Lightness and simplicity of working parts powerfully contribute to economy of fuel, and I think we are justified in expecting to see great adrances wade in the future in these directions.

Here is a small medel of an engine of norel construction which I have recently met with, which appears to me to offer peculiar advantages in mans points for marine use, and which, if I am not greatly mistaken, has a future beforc it. Half the cases of stcam ships breaking down arise from either the crank or the connectiner-rod breaking. This engine dispenses with both. The speciality which first attracted my attention as marking it as peculiarly adapted for marine use, is its economy of space. It requires only fire-eighths the space of the shortest connecting-rod encine, whilst in regard to friction I think it will compare advantageously with the trunk cngine.

I am also assured, on testimony on which I can rely, that its arerage weight and average cost will not excecd five-cighths of that of mariue engines of the ordinary form. $\Lambda \mathbf{n}$ enrine of the kind, of 20 horsepower, has now been in conslant work uight and day for two years pumping the water for a paper unill in the vicinity of London withont. once requiring repair.

Besides lending the model for exhibition this erening, the proprietor has bindly giren me permission to invite any gentleman interested in the subject to see the pumping engine at work.

There is one phase of the question of cconomy of fuel on which I have not touched, viz., that concerned with husbanding the resources of the steam-power at command; on what oceasions slow speed should be used, and on what the use of steam-power dispensed with altogether. But these are questions of seamanship on which it would be presumptous in me to offer you advice, and if not presnmptous, superfluous, since the subject has been most ably landled by a gallant Officer whom I hare the pleasure of sceing here to-night, $\Lambda$ dmiral $R y d e r$, in a book well deserving of being more widely known.

The Cramsax: Is yours a self-acting apparatus to admit the air?

DIr. Pridesex: I daresay the SIcmbers of this Institution are amene that I hare been at work at this subject for a rery long period. This dratring repreeents the first apparatus tlat I bad for sclf-closing. 'This is a wafer eylinder which is fitted with a rulcanised cap of india-rubber. This piston is the same kind of piston as is uscd in the hydraulic press. You may more it up rapidly, because the india-rubber side collapses and allows the water to pass. When it is up, the india-rubber expands by the pressure, und it can only pass down as the water below trarcls through this small aperture (the size of which is regulated by a ecrew), and comes orer the top. The only defect in this apparatus waz, that it wanted to be filled with water every das. When it wns filled erery day the india-rubber piston lasted, on an arerage, nine montlis. In fict, it just amounted to this, that when the enginecr took interest in the thing, it was easily kept in worbing order. In the ". Irgus," under Captain Gisndy, it worlicel crecedingly well. Sulnhur is used in. 
the preparation of rulcanised india-subber, and I lad a few cases where some peculiarity in the water induced chemical action, and crystals of sulphate of copper were deposited; but the occurrence was rare. 'There is no doubt that this new apparatus is a considerable improvement upon the water crlinder. It cntircly dispenses with iny superintendence; it does not require any filling up.

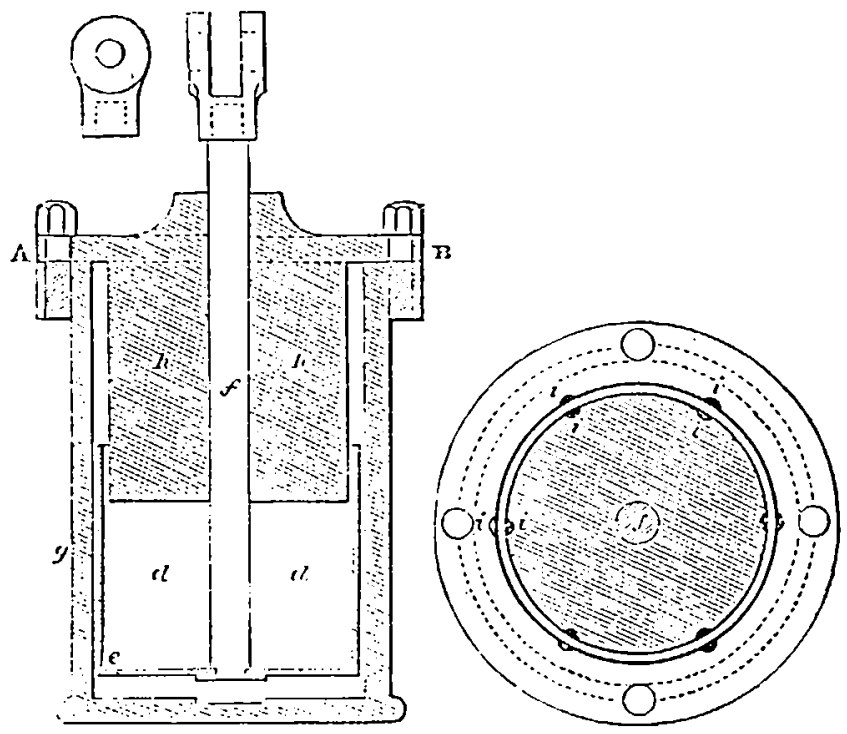

The cistern, $d$, being filled with wercurs and placel at the bottom of the cylinder, $g$, upon raising the cistern, the cylindrical plunger, $h$, enters the cistem, causing the mercury to flow orer its sides and pass through the groores, $i$, to the bottom of the cylinder. The raising of the cylinder rod lifts and opens the air-valre, when the wcight of the flap, slightly depressing the cistern, causes the mercury to rise in the groores and round the sides of the eylinder considerably abore the lerel of the hottom of the cistern, and, as a consequence, to flow into the cistern through the small orifice, $e$, causing it gradually to descend and the air-vaire to close in a time proportioned to the size of the orifice and the area of the cistcm. This apparatus will mork from an hour to a minute. 'That is set for six minutes, which is about the arerage time for a unaine furnace. I have had this apparatus rorking six months in a stokehole, without any eap orer it. You obserre it is capped like the rorks of it watch, so as to prercut any clust getting into it. I fecl rery confident it would work throughont the three years of a ship's commission without once requiring adjustment. In fact, I sce wo riuson why it slould not work for twenty years.

The Cramsis: When you open the furuacedoor, it opens the ralre-bos, and after you shut the door, the :pynitratus grolually shuts itsclf, and cuts off the sipply of air.

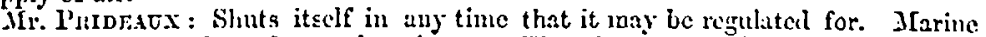
furuaces would be from fire to sir minutes. The cistcru contains $\bar{j} \mathrm{lbs}$ of quichsilver.

Captain Bengsss: What is the cost of that appuntus, including the fitting of it?

Mr. Privesex: 1 single one is about $f 20$; if there are sereral of one size they come to less.

Captain Hosedsos: What is the royalty to an cuginecr? 
Mr. Pripeacx: That includes rosalts and crerything,-the cntire cost.

The Cinsmasis: I think you will all agree with me that this is a most impertand kubject that Mr. Prideaus has lectured upon. I think no engincer or naral man can differ as to the great importauce of some apparatus for consuming smoke. The only question, it appears to me, is what is the best plan for accomplishing the object. Ir. Prideaus lias esplained rery elearly, both in his lecture and by his diagrams, that there rould be a rerr great saring in the consumption of fucl according to his plan; and $X$ hare not the slighte t doubt about it, as lone as this apparatus works properly, and the door is bept clear of dust and dirt. The only thine that puzzles me is, that the plan has becn before the $\Delta$ duniralty so very long, and they hare not adopted it. But that does not at all imply that it is not the right plan. We all know that the $\Delta$ dmiralty very often take up plans which, in my opinion, they ought not to take up, and cast aside plans which thes ought to take up. According to what I understand, the plan for consuming smoke that thes hare adopted is the plan of Mr. Murdoch, a naral cnginecr. It acts upon a dillerent principle from that of Jir. Prideaux; instead of a current of air orer the top of the fire, it admits the current of air at the back of the bridge; and it equally consumes the smoke. IBut this (Jrr. I'ricleaux's) apparatus does not interfere with the size or proportions of the furnace at all. I suppose crery engineer when lie males his engine calculates the size of his fircplace, and that everything is most corretly proportioned. If you take his (Mr. Murdoch's) furnace, and cut of one-fifth from the end of it, supposiug it is calculated to burn a certain quantity of coal, you dianimis his power of producing steam. Therefore, if all the firepliaces in the Nary are to be altered on Mr. Murdoch's plan, and thiz plan of Mr. Pridcaux's would answer equally well, without the necessity of making any alteration in the furnaces, I think it would be preferable to adopt it. I hope some gentleman will gire us lis opinion on the subject.

Alniral Wfilfistr, C.B.: If I am mot trespassing too soon, there is one point. with regard to this subject which Mr. Prideaur might explain. It is with reference to these selfacting doors. If I understand rightly, when that door is open the quicksilrer is pumped up, or whaterce the process may be, and as long as the door is open, nothing takes place. But the moment the door is slut, the ralre begins to act, and then firc minntes must clapse before it has gove dorn again. Supposing the engineer to walk along his stobeliole, and that he wants to hare a look at liis fires as he gocs along, in order to sce that his people are doing their work properly, he throws all his doors open cach time, aud consequently the monacnt he opens the fire door the quicksilrer is pumped up again, the ralre is raiscd, and the process is all fone tlirough again needlesslr. Then, again, it is no norclty admitting the air orer the top of the fire-place. It lias been done bjour engincers for themselves; thes lare been in the habit of perforating the front door ; but the dificulty they had was that the holes were almass there. As I understand it, the merit of this plan is that it is a eelf-acting appamtus. It would be so if you were almays to fill sour furnace by mans of it, and let the fire remain thirtecn or fourtecn ininutes. But that will not do for a maral cuginecr, who wants to be going along, constantly, looking at his fires and haring his doors open. As I understand, cre's time that door is opeu, the ralre is raised again, and it requires fire or six minutes to closo the ralre. I onls want to know whether the cngineer can clisconnect it in any way.

1. With regard to the question of price, $I$ am desirous of obscrving-

Ist. That the dimensions of the air-passares in cach furmace-door and front are a matter of calculation, cach having to be constructed with reference to the furnace for which the door and frout is designed.

2nd. That the norkmanship requires to be of the best charicter, and great solidity, to maintain the apparates in working order, amidst the dirt and heat of the stokehole from one Jenr's and to another, without requiring ercu clcaning, a desideratum attained for the first time, in the present apparatus.

3rd. That, on an arerage, the price charged, is repajed by the saving of fuel in three montlis.

4th. 'That I hare always offercd to accept sis months' saring of fucl, as payment for the apparatus. 
Mr. Pridfux: Fou necl not make the air valre sclf-opening. It iz perfectly cass to make it the duty of the fireminn to open the valre after coaling. Then of course it would not open of itself with the opening of the cloor. But if the engincer opens the door to look at the fire, when he shuts the loor he has onls got to close the ralre down at once. Fou cannot bire it both ways. Holes that are al wass open admit about sir times as large an air supply as this apparatus.

Admiral Wes.resLer: Supposing the enginecr should mish to look at his fires before it is time to coal, then by opeuing the door the opens the air-feed.

Mr. Peidesex: At first I did not mabe it eelf-opening, but onls sclf-closing, maintaining that jou onght to hare fjecmen euficicutly intelligent to understand and renember that when they shut the door after coaling they liad to lift this air ralro up, and then it would shut itself. But we find that our customers generally prefer to hare them self-opening as well as sclf-closing; but jou can shut the air ralro down close at any noment if desired.

Admiral Wellesler: Esactly; that meets my question.

Adniral RrDer: You Epoke of the tin sliclds.

Mr. Pridestix: What 1 call a non-conducting shich. They are closed air cham. bers of tiu. Air is an cxcecdingly bad conductor of licat. These shiclds are serewed on to the fluc doors. They aro very slight and casily tuien off.

Rear-Admiral RrdeIl: Mr. Prideaus has kindly alluded to a work of mine on "Fconomy of Fucl," long out of print, published some twenty ycurs ago, which touched upon rarious parts of this subject that he has not alluded to. The subject is a rerg wide onc. I sm sure it could not be discussed properig to-night ; I donbt if it could be discussed in Icssthian two or three niglits. "Economy of fucl" includes many branches; I will run over a few of them, very shortly, to show what a large sulject it is, and what a great cleal there is in it. The particular branch of the sub. ject dwelt upon by the I.ecturer, riz., the int roduction of air into the furnace, is very important, and his doors appear to meet the difficulty. After considering the title of the paper in all its rridth, onc ma fairly say that the question cach naral Office would maturally lase asked himself before coming here to-night was, what part of this rery large subject, "IIow can the cconomy of conl be bust promoted in "the Nary," is to be considered by Mr. I'ridcaux to-night. We now know, thanks to the most interesting and instructive paper read by Mr. Pridcaus. Well, bat let us take the broadest part of this rery wide subject first, riz., the question as it must. be considered at head quarters. It once we find ourselres face to face with that moot question, Whint is the most suitable and most economical hind of fucl to be supplicd to ships of war, and are the terms courcrtible? This is a very large subjest with which naral Coficers in command of elips hare practically nothing to do, for we must take mlat coal is giren to na, and make the best we can of it. Another very important question relates to dejout s of ccal abroacl. This bears also, like the preceding, upon econoung in the gross sum expended upon coal ycarly. The necessity of our having numerous fortified depôts for coal, the ccul being corcered and not bept too long, was touclicd upon in a very interesting paper rencl Iast joar by Captain Hoscason, R.T. This, again, is a very large subject, and a most inportant one, which would take a long time to discuss. We hare all heard a great deal lately of the question of the "mised conl" which is now supplicd to the firy. I hope we shall eoon hare some some facts from the $\Delta$ diniralty detailing the experiments which lare becn tried across the IIclitermanean, and comparing the cconomical merits of Welsh conl with those of the Admirulty mixture, and of north country coul by itself. I beliere, from what $I$ lase heard, it will be slown that Welsh coal is rery mucls more economical in all respects, cren to the extent of 20 per cent., than the "mixture." At the same time there is this to be said on the ofher side, nnd it nust not. be forrotten, viz., that the Welsh coal, if stonch in the tropics, is said to detcriorate sooncr, owing to its friability (not to any chemical change) than all other hinds of conl. It is well, thereforc, that our furmaces should be litted, if possible, so as to

* In point of fact, lowerer, opening the door a little to look at the fre lardils opens the ralre at all; aply when the door is thrown mille open, as for firing, is the ralre ridely opened. 
burn Welsh cosl well and econonicalls, and also to burn well and econumicully other kinds of coal, if, indeed, ne can hare furnases so fitteil. If we cannot, then I agrec with Lord Lauderdale we liad better hare our furnaces fitted to burn, at all crents, well and economically the Welsh coal that we shall endearour to supply our ehip. with in mer. Experiutents ou the relatire merit 3 of differeut descriptions of coal under allecircumstances should be commenced at once.

The Crimerse: We must frst be satisfied that the north country cosl docs keep better in a hot climate than the Welsh. I cntircly dispute that.

Admiral Rypro: Perlans you may be right, but I only say it has been stated so. The person who gare me the information mas Rear-Admiril Sir. Whilliam Mends, who has laad a grest deal to do with coal depotz for truop-shipa. 'Llue information he gare ne was in print, and professed to be a report on the deteriontion of coal abroat. Thesc are two of the points which occur to no as foming the broxlest part of the subject.

When we are treating of the economy of fucl in the Fiers, we at once see the in. portance of our haring the most cconomical engines and boilers in the shiju, economical as regards the consumption of fucl, as well as of wear and tear. 'Lhe Com. mittec of Iesigns, of which I was a member, receircd inuch cridence on this point a fer monthis since, and satisted themselres that the compound cngine is by far the most economienl engine that we can have, and that the pressure on the boiler is leing increased jcar by sear. The compound cngine will burn a less juantity of coal per indicated horse-power than ans othei, approaching to $1 \mathrm{lb}$. per indicated horse-pource per hour. 'The cxpansion gear should cut ofl as carly as onc-twenticth of the strobe, and the ports should be nuwh increased in size. Having got our cngiue and boiler on board, and the ship in our hands, the question, of course, prescnts itself, what is the most cconomical way of manging the fucl when you haro got it on board? 'There is no doubt stout it that the moro you can usc sail, and the less you rely upon coal, eimply quí cconomy, the better. It is then a very impurtant. question to what estent should our ships be masted, and to what catent should thes lare cugines? This is a large question, indeed, and it would take a rery long time to discuss. I am of opinion that no slip-of-war, escept ressels for harbour defence only, should be without a sail equipment sufficient at least to make them mauage:able in a gale of wind, and aid them in mabing passages, and that the majority of our men-of-war should be fully rigred, and fo construeted that thes should be able to beat to nindward under all plain sail in smooth water more than one mile an hour.

In the next place there is the most inportant question of rolkind steam expansicely, which I am sure Captitin Hoseason will allude to yreseatly, as he enn speul on it mith worc wcight than $I$ can. It is a question which ought to interest all naval Offecrs, and which $I$ am afraid is often orerlooked by those of them before whom it has not becn properls brought. I liare, when taking passoges in shiph.of-nar, been startled to see low little the expansion ralres of the engines were considered or used with judgment, and how often ships were burning a great desl more conl than they ought, simply because the stcann was not used as expensively si it ought to be. This, also, is a rery lange question which would tabe a long time to discuss. There $i$; another matter germane to it which has often oceurred to me, nud especinlly when I nas last afluat. I communicated with the Admirilty unon the subject, nad thes desired me to draw up a draft. cireular on Economy of Fucl. A part of this circular was adopted.* The point I roised N23 this:- I think it. will be admitted by erergbody, when they consider the subject, that alwags in ships mithout masts, and frequently in masted ships, with foul nind or calms, stean must be used, but that. if there is no particular object in reaching your port on a particular day; the most scononical speed for the voyage mill be, ceteris paribus, that which will cause the

* Since this paper was rend, a nother Circular las been issued, dated April 20th, 1872, adopting the recommendations made by une to their Lordships tliree fears since, viz., that the speed which was the most cconomical per mile shonld be ascertained at th. carliest opportunity in crers ship, in colm weather, should be renorted to their Lordships, and be always maintained under ordinary circumstances. 
least consumption of fuel "per nile" (5ou must alway carefully distinguish between "per mile" and "per hour"), and which will be cither under sail alone, if there is no urgency mhateser in the orderz, or elso some definite speed to be asceitrined by experiment. Now the most economical epecd under stcien "per rosage" and per inile, is probably to go as slauly as possible. Of course it is, I hear some one say. But though erersbods says "of course it is," they don't practice it. You will rarely find when you are cruizine that the ressel is goind as slow as possille, and if you suggest that she slould only go three and a-haif or four bnots, you rould proliably not be beliered, and it would often be considered an absurdity by the Captain that be should be expected to reduce speed to three and a-half knots in a ship that can go fiftecn. . I do not say this is the univereal feeling, but I know there is such in fecling. Onicers hare thought that no one has any right to hint eren at their going less than seren or eight hnols under steam alone, but lately, I beliere, some ironclads hare reduccd their speed to two and a-half knots-so I haro been told, and bare ecen in reports. When there is no object in going any quicker, the slowest, speed iz, as a rulc, in light winds, or calms, and smooth winter, the nost economical speed per mile, on account of the resistance varying as the square of the specd, or neirly so. Of course we must look at both sides of the question. There is a epeed in some engines which racks the cngine, aud causes backlask, to which the eneines must not be reduced, and which although it minth be tlic most cconomical speed, might injure the engine; this you hase to guard against. But Officers in command should not speculate as to what is the most cconounical spect per mile when the breeze has freshened, or a scat got up, they should always a seert nin it. If they take a little pains thes can do so, and it will vary with the conditions of seir and wind which are happening at the time. Having determined what is the most economieal spect per nile, they should maintain it. Of course they can proced more quickly at any time, if there is reason for it. This is a rery inportant point connected with "ciunomy of fucl." Captains should always be asking themsclres day b5 day, and hour by hour, whether they are steaming at the nost economical speed per sile, and if not why not? Onc of the questions which came on the other day before the Committee on Designs (the report is on the table of the IIouse of Com. mons, and no longer confdential) was this-In our large ships we have enornotis engines of 1,200 liorses noninal, working up to 7,000 indicated horse-power. If, as I maintain is true, the slowest possible epeed iz, under ordinary circumstances, the most econornieal per mile, and therefore per voyage, or when cruizing, then we are leil up to this consideration, viz., that we hare enolmous engines with great friction, requiring constant supply of lubricating material, which must, somehow or other, be alriass driven along, eren when we only want to maintain a epecd of say three or four bnots. Just as if a mu, when driving his one horsc coil cart, insisted on fistcuing all his stud to it, aud dragging them after it. It is crident that iliere will be considerable loss in driving this mouster, while we only waut to maintain this speed of say 3 lnots, and for which 200 or 300 indicated horse-potrer might be sufficient. Therefore, a suggestion was made, that in designing the engincs for theso large shipa a small portion of (probabls the after part of the cngine, saj one eighth, or 150 nominal horse porrer, slionld be capable of being discomected from the rest of the engine, and be used for all ordinury oceasions, viz., when you want the ship to go as slow as possible, and, therefore, as ceonomically as possible. The Chicf Engineer of the Admiralts, Jr. Wright, ndmitted that this would be an cconomical proceding. Fconomy of fuel in war time will be erergthing, it will tend to ensturo auccess.

The Cinamsax: I should say with two and a-half bnots you will neree get to the end of the royage. Gire us a half speed of ten linots.

Admiral RYDER: Ten knots is, I admit, a rery comfortable speed, so is that of the cxpress train; but it may be a ruinonsly extraragant speed, eren in a fiftecu kuot steamer. Of course, if cosl were not an object, it is the speed one would prefer to any slemer. I haro crossed the $A$ tlantic in a steam line-of-battle-ship (the "Hero") at a specd purposely reduced throughout the rogage to from three to four knots, in light head winds and calms, when had I attempted to go faster, I should not hare reached my port (Bermuda) for ncols. There is anolher question with regard to " cconomy of fucl," which came before 119, rery promineutly, which is alluded to in the Com- 
mittce's Report, and is also adranced I ece in the Immull just published by the Professors and others of the School of Sirral Architecture, fensington, riz., that the "turbine" promises, when thoroughly developed, to be a rers economical propeller, perhaps the most cconomical. It is uncli to be lioped that the Admiralty will now take steps to carry out most thorough experinents with rerard to the turbinc. This is the uramimons recommendetion of the Committce on Designs, one of the few important points on which they wcre unanimous. There is an impression abroad that the turbine anust be a less cconomical propeller than the ecrew : but the writer of the article referred to speaks of it, as at all crents theoretically, the nost ceonomical of the tiro. Its numcrous other adrantages are manifest, and haro often been pointed out here. I haro suggested to the Admiralty that to promote "cconomy of fucl" at sca, when under steam, au entry should be made erery day by the Captain in the log at noon, and oftener if necessary, replying to the following questions: 1 . What specd are you maintaining? 2. What fuel are you epending per mile? 3. What speed would be most econonical in fuel per mile at this particular time, cit leer as cstimated or ascertained, by diagram? 4. If you are not procecdinc at the spect which is the most economical per mile, why not? If this were ordered to be done, and Commanding Offecrs had erery day to make that little confession, as it were, to their Commander-in. Chicf and the $A d$. miralts, I am sure that a rery renarbable reduction in the total cousunption of fucl throughout the Scrrico mould take place : because when a man had to answer these questions daily, it would often puzzle lim to find and to gire ang sufficient reason why le was not etcaming as cconomically per mile, which is per royage, as be might. He would thus be led gently, but by an irresistibly persunsire pomer, to practise the utmost cconomy, not a scoscless cconomy, imperilling the ship, but a wise and judicious ceonomr. An order to the abore effect would also tell upon the senior Ofliccrs, commanding flects and squadrons; and they would ccrtainly adopt the plan of more fully cxplainiug than at present to the Cajtain in their sailing orders, either the urgency or nou-urgency of the orders, or state the day beyond which it was not desirable their rojage should be extended.

The indicator diagram, that inraluable aid to the Captain, as rell as to the cngineer, tells us by the "terninal pressure" what is the relatire "consumption of fuel "per "rerolution," and therefore per mile, when the epeeds compared are not. widely different. Suppose that the speed has been maintained in a calm at the slowest specd possible, without backlash or racking, say $2 \cdot 5$ knots, and that that speed has been nscertained by aid of the diagram to be, in a calm and smooth water, the most cconomical per mile. The wind freshens to a steads brecze abead, and the rerolutions (sas 20) which drove the ship 2.5 knots in the calm cease to drire her nhead more than 1 knot. The 20 rcrolutions must cridently be jucreased, but by how much? The experiment elould be conducted in this way:-Inerease the revolutions by say two or thrce at a time, usiug tle cxpansion gear of coursc, usccrtaining the speed, and taking a diagrum at cach iucrease of rerolutions. Then the

$$
\text { No. of revolutions } \times \text { terminal pressure in tenths of inches }
$$

will gire a comparative measure of the consumption of coal per mile at cach speed, and the fraction which jields the emallest quotient will hure as the specd inrolred in it the most cconomical speed per milo for those circumstances of wind and eca.*

* Example.-The brecze laring freshened ahead, tho number of rerolutions (20) which had preriously driven the ship 2.5 knots now only drives her 1 bnot, increase the rerolutions successirely to $\$$ ia $23,26,29,32,35$, and let the mean termiual pressures on both sides of the piston be $10,11,12,13,14,15$, and the epeeds 1,2 , $2 \cdot 8,3 \cdot 4,3 \cdot 8,4 \cdot 1$, then $25-$

$$
\begin{aligned}
& \text { (1) } \frac{20 \times 10}{1}=200 . \\
& \text { (2) } \frac{23 \times 11}{2}=126 .
\end{aligned}
$$


Steaning against a current, the most economical specd is approsimately half as fast again as the current. If current 4 knots, specd through the water should be 6 knots, orer the bottou, 2 knol 3 . As I said at the commencenent of ms remarks, the title of the paper is so aride that I hare becn scclured into greater discursireness than $I$ intended. I wish 3r.: I'rideaux all success.

Cuptain Hosmasox, R.N. : As my friend, Adminal Rjder, liaz alluded to me in his obserrations, especially as to that cconomy of fuel that is derived from the expansiro action of stcam, I hopo I may be able to say a fer words which will, I trust, be a course of consolation to the lecturer. IIe has told 13 how many years he has treated upon this all inportant subject, the cconomy of fucl, and for what a lengthened period he lias becu engaged in endearouring to mush forward his iurention, and that he has encountered little more than a passire resistance at the hands of the Lords of the Adniralty. Yet we all agrec that the abatement of the smoke nuisance is one of rital importance both as regards coficiency and cconoms in steamers. There is no want of lucidity in the lecturer, therefore if those at the fountain lead do not see their way clearly, it camnot be from want of having the facts placed elearly before them.

I also have been a labourer in the same vinegard with himself. It was in the year 1812, I frst brought my riews of the ccononis of fucl to be derived from a still further derclopment of the espansion of steam before the Admiralts, and in the jear 1872 I find the s:abject but little understood and still les3 cared for.

The Lords of the Aimiralty caused the following letter to be written to me, dated 19th Jul, 1812 :-“ I am commanded b5 my Lords Comraissioners of the Admiralty" " to return you their thanks for jour communication on the subject of using steam "crpansircly, and to send you the necompinging copy of amemorandun they are "about to issuc on the subject to the Commanding Officers of all IIer MLajesty"s "stcamers."

They sent une the memorandum in question without erer haring consulted me as to its composition, and when I came to perusc it, I found it drawn up in such Figlish, and so unscientific, that I felt myself in duty bound in respect for ing onn reputation, to fully analyse their Lordships' Circular, which will be found contained in the pawplilet I loold in my hand, and which I bere present to the Institution.

The lecturer in introducing this paper lias, as Admiml liyder statez, opened up a rery large and important question, which is daily growing in importance, secing that our Naral and mercantile steam tlects are now nearly entircly composed of ressels whose primary porrer is steam. And I hare only to regret that we should be called upon to discuis ofl land so large and dificult a subject, and with our time, after. haring the paper read, so much rest ricted.

Tho Cinsmins : I think jou will all agree with me that re onglit to thauk JIr. Iricleaus for the very interesting lecture he has giren us. I only wish we had more tine to mork out the subject, and that he rould cspind it to greater length. There would be more questions put upon the subject, because when a subject is

$$
\begin{aligned}
& \text { (3) } \frac{26 \times 12}{3.5}=112 . \\
& \text { (4) } \frac{29 \times 13}{3 \cdot 1}=111 \text { (the minimum quoticnt). } \\
& \text { (5) } \frac{32 \times 14}{3 \cdot 8}=118 . \\
& \text { (6) } \frac{35 \times 15}{4 \cdot 1}=128 .
\end{aligned}
$$

No. 4 , viz., 29 rerolutions, giring a epeed of 3.4 hinots, appears to be the most ccono. mical spect per mile, as 111 is tho minimum quotient. 'This case is giren mercly in illustration, and does not pofess to be a lona fide cxperiment. If time admits, the actual expenditure of fucl per mile should of course be ascertained. 
brought before a meeting of this sort, and only partiilly discusecd, rery little good results. There is no doubt of the necessity for consuming $\varepsilon$ mokc, but the question is whether or not the smoke can be consumed. Mr. Prilcaus contends that by his plan there is a gain of fuel; many enginecrs contend that the smoke cannot te consuned without is loss of fuel. There is a woulerful difference between the two. It would be of great importance if the question conld be worked out and discussed. Perhaps JIr. Prideaus would answer any obserrations that hare been made.

Jir. Punfidx: I think that whist foll from Admiral. Ryder and Captain Hoscason hardly related to the particular department of economy of fucl which I hare treatcl on to-uiglit. With regard to what your Lordship said, I would just obserre that the distinctire difference between Mr. Murdoeh's plan and this plan is, not co much the part of the furuace in which the nir is admitted, though that is a considerable point. 'There is no doubt that it is more injurious to admit a continual supply of air abore the fucl at the bridge than it is at the door. But the distinctire difference between the two plans is this, that Mr. Murdoch's, if it is to be called JIr. II urdocl's, is one of the old plans in which the shutting off is icft to human ageacs. I maintain that that is never to be relied upon, and that it is impossible by this means t) regulate the air-feed correctly, beculse if yon liad a man to stand with a watch in his hand, to shut it off at the expiration of five or six minutes, which you would nerer get a man to do, even then twico the right quantity of air rould cuter the 'furmace. It has been tried orer and over again, and it has almays been abamloned. When I licard the Aduiralty were trging to burn "Baster's mixture" on such a system, I predicted from the first that they would nerer aceomplish it. But if they had had this automatic apparatus, they might hare burned the conl very well. I have proved it in ressels thist rere buruing all Newcistle coal. I tried it in the "IElfin." For" two hours Admiral Demman and mysclf steanned through the flect at Spithead at full epced. So copious was the stcam supply, that we liat? only there fires lighted out of four, and I do not think at 100 yards' distance anybody could lave told from the top of the funnel that there was a fire on board the slipp. It was all Newcastle coal. On the deck of the ship, as cach shovel full wits throm on, you could sce a trace of dust; but the moment the door was shut, it was all clear. No alteration was made to the furnace bars; the only alteration made was the substitution of my door for the common door. It certainly prored that Newrastlo conl conld be burned without smoke, in the ordinary marine boiler of the "Elfun."

Admiral Rruen: Do you siy that the burning on that occasion was more cononical tlan if you had Welsh coal with your door?

IIr. Prideacx: I belicre Nercastlo coal with this loor will answer as well as Viclsh coal.

Aduimal Rroen: The door in use in both cascs?

Ir. Pridfux: I think the result is about the same. Certainly, with a mixture of half Nerreastle and half Welsh, if the furnace was fitted with one of these door. you would not sco any smoke from one month's end to another, and you would have a great cconomy of fucl; and, certainly, an increascl quantity of stcam. 